\title{
Synergistic effect of acetyl xylan esterase from Talaromyces leycettanus JCM12802 and xylanase from Neocallimastix patriciarum achieved by introducing carbohydrate-binding module-1
}

Yueqi Zhang, Hong Yang, Xinrui Yu, Haiyang Kong, Jiaming Chen, Huiying Luo, Yingguo Bai ${ }^{*}$ and Bin Yao*

\begin{abstract}
Wheat bran is an effective raw material for preparation xylooligosaccharides; however, current research mainly focuses on alkali extraction and enzymatic hydrolysis methods. Since ester bonds are destroyed during the alkali extraction process, xylanase and arabinofuranosidase are mainly used to hydrolyze xylooligosaccharides. However, alkali extraction costs are very high, and the method also causes pollution. Therefore, this study focuses on elucidating a method to efficiently and directly degrade destarched wheat bran. First, an acidic acetyl xylan esterase (AXE) containing a carbohydrate-binding module-1 (CBM1) domain was cloned from Talaromyces leycettanus JCM12802 and successfully expressed in Pichia pastoris. Characterization showed that the full-length acetyl xylan esterase AXE + CBM1 was similar toe uncovered AXE with an optimum temperature and $\mathrm{pH}$ of $55^{\circ} \mathrm{C}$ and 6.5 , respectively. Testing the acetyl xylan esterase and xylanase derived from Neocallimastix patriciarum in a starch-free wheat bran cooperative experiment revealed that AXE +CBM1 and AXE produced $29 \%$ and $16 \%$ reducing sugars respectively, compared to when only NPXYN1 1 was used. In addition, introduced the CBM1 domain into NPXYN11, and the results indicated that the CBM1 domain showed little effect on NPXYN11 properties. Finally, the systematically synergistic effects between acetyl xylan esterase and xylanase with/without the CBM1 domain demonstrated that the combined ratio of AXE + CBM1 coming in first and NPXYN11 + CBM1 s increased reducing sugars by almost 35\% with AXE and NPXYN11. Furthermore, each component's proportion remained the same with respect to xylooligosaccharides, with the largest proportion (86\%) containing of $49 \%$ xylobiose and $37 \%$ xylotriose.
\end{abstract}

Keywords: Acetyl xylan esterase, Xylanase, Synergistic effect, CBM1 domain, Xylooligosaccharides

\section{Introduction}

Plant cell wall is mainly composed of cellulose, hemicellulose and lignin (Bastawde 1992). Xylan is an important component of hemicellulose in plant cell wall and makes up approximately $35 \%$ of the dry weight of the cells (Chakdar et al. 2016). It is the second most renewable organic carbon source in nature next to cellulose. Xylan

\footnotetext{
*Correspondence: baiyingguo@caas.cn; binyao@caas.cn

Key Laboratory for Feed Biotechnology of the Ministry of Agriculture,

Feed Research Institute, Chinese Academy of Agricultural Sciences, No. 12

Zhongguancun South Street, Beijing 100081, People's Republic of China
}

is a kind of complex polysaccharide, and its main chain is a plurality of pyran xylose residues linked by $\beta$-D-1,4 glycosidic bonds (Biely et al. 1997). However, xylan is a highly polymerized polysaccharide with a wide range of structural changes and branched heteropolysaccharides (Peralta et al. 2017). Different sources of xylan, yield different degrees of branching. Its side chains usually have different substitution groups, such as ferulic acid, $O$-acetyl, coumaric acid, and pyran glucuronic acid (Biely et al. 1985). Acylated xylan is common in hardwoods, and the degree of acylated xylan C-2 and C-3 in the main chain can reach between 50 and $70 \%$, while most of the 
hydroxyl groups of xylose residues are esterified by acetic acid. Therefore, in the process of biodegradation of xylan, the degradation of acetyl groups with high contents of substituents is particularly important (Collins et al. 2005). Acetyl xylan esterase hydrolyzes the $O$-acetylated glycosaminoglycan on the $\mathrm{C}-2$ and/or $\mathrm{C}-3$ residues of acylated xylan (Biely et al. 1985). The acetyl group interferes with the access of the main chain enzyme in terms of space; therefore, acetyl group removal may enhance the affinity between the enzyme and xylan, thus promoting the effect of xylanase.

Xylooligosaccharides are composed of 2-7 xylose subunits linked by $\beta-1,4$ glycosidic bonds. Compared to other oligosaccharides, xylooligosaccharides have many unique functions. They have good acid stability compared to oligofructose, and are extremely resistant to high temperatures (Chen et al. 2009). They also have a strong function in the proliferation of intestinal probiotics, including the highly selective proliferation effect on bifidobacteria, lactic acid bacteria, and other probiotics. In vivo experiments in rats showed that xylooligosaccharides could not only increase the proliferation of probiotics, but also prolong their survival time. In addition, in vitro experiments showed that all bifidobacteria could utilize xylo-disaccharides and xylo-trisaccharides. And these molecules improved ecological balance of microorganisms in animal intestines, producing organic acids and other beneficial substances and reducing the production of ammonia and other decay substances in feces, preventing environmental pollution (Yang et al. 2018). Experiments by Reddy SS and Krishnan $\mathrm{C}$ also proved that xylooligosaccharides improved the metabolism and enhanced the humoral immunity of poultry (Reddy and Krishnan 2016).

Currently, the raw materials used to prepare xylooligosaccharides include wheat bran and corncob. Wheat bran accounts for $20 \%$ of wheat processing output as a by-product that is of low economic value. It contains approximately $40 \%$ xylan which can be divided into water-soluble and water-insoluble xylan based on solubility, with the former constituting approximately $6 \%$ of the xylan content in the bran and the xylan being insoluble (Maes and Delcour 2002). Wheat bran xylan and other components of the cell wall (such as lignin and cellulose) are interconnected, and most can be extracted only in alkali solution, as the amount of xylan obtained in direct water extraction is very small. The commonly used methods for xylooligosaccharide extraction involve physical methods, such as hot water extraction, and steam blasting and chemical methods, such as acid and alkali extractions (Rastall 2010). When an ester bond encounters a strong base, it breaks itself. Therefore, many studies focused on the synergistic reaction between xylanase and $\alpha$-L-arabinofuranosidase in production; however, little work has been done on the synergistic effect of acetyl xylan esterase and xylanase. Alkali extractions of xylooligosaccharides have high recovery efficiency, however, due to the chemical extractions process, consumes considerable amounts of acid, alkali, and ethanol, which pollutes the environment. Since biological methods are relatively safe, the introduction of acetyl xylan esterase and xylanase together is of particular interest. The present study aims to introduce the synergistic effect of xylanase and acetyl xylan esterase on insoluble substrate, as well as analyze of the products for xylooligosaccharides. After acetyl xylan esterase was first discovered by Biely in 1985 (Biely et al. 1985), different types of enzymes have been increasingly discovered and studied. The study by Selig showed that xylanase and acetyl xylan esterase exhibited synergistic effects on the hydrolysis of acetyl xylano (Selig et al. 2009). Puls found that the addition of xylanase and acetyl xylan esterase in different orders not only affected the degree of hydrolysis, but also affected the composition of the hydrolyzed products (Puls et al. 1991). Another study found that adding acetyl xylan esterase can improve the solubility and degradation speed of xylan (Cybinski et al. 1999). In case of an acetyl xylan esterase deficiency, it is difficult for xylanase to move close to the main chain of the highly acetylated xylan; due to reduced accessibility; however, application of acetyl ester enzymes enhance the affinity of xylanase for xylan (Mcdermid et al. 1990).

The xylooligosaccharides enzymatic production method is safe and pollution-free, and the hydrolyzed bran can be further recycled as a favorable feed material (Rastall 2010). However, the recovery rate achieved using this method needs to be improved. A previous study showed that carbohydrate-binding module-1 (CBM1) domain helped GH10 xylanase in hydrolyzing washed corncob particles (Miao et al. 2017). Moreover, Cel5ACBM6 transgenic plants were $33 \%$ more efficient than Cel5A transgenic plants in directly transforming native tobacco cellulose into free sugars (Mahadevan et al. 2011). In this study, the acetyl xylan esterase gene cloned from Talaromyces leycettanus JCM12802 was expressed in a Pichia pastoris system, and the CBM1 domain was introduced into the xylanase gene from Neocallimastix patriciarum to investigate their synergistic effects on starch-free wheat bran.

\section{Materials and methods}

Strains, vectors, plasmids, kits and culture conditions

The vector PPIC9 was used for construction of the gene, and Pichia pastoris GS115 (Invitrogen, Carlsbad, CA, USA) was used for host protein expression. Escherichia coli Fast1-T1 (Vazyme, Nanjing, China) receptive 
cells were used for DNA cloning. T4 DNA ligase purchased from New England BioLabs (Hitchin, UK), was used to connect the genes and vector. Recombinant Pichia pastoris was collected from minimal dextrose solid medium (2\% glucose, $2 \%$ agarose, $1.34 \%$ YNB and $4 \times 10^{-5} \%$ biotin) and placed into YPD medium (1\% yeast extract, $2 \%$ peptone, $2 \%$ glucose) for 2 days, then saved in an equal volume of YPD and 40\% (weight/volume, W/V) glycerol at $-80{ }^{\circ} \mathrm{C}$. Recombinant $P$. pastoris AXEs and NPXYN11 s were enriched in BMGY medium ( $1 \%$ yeast extract, $2 \%$ peptone, $1 \%$ glycerol, $1.34 \%$ YNB and $4 \times 10^{-4} \%$ biotin) for 2 days at $30{ }^{\circ} \mathrm{C}$ with shaking at $200 \mathrm{rpm}$, then the yeast harvested by centrifugation at $4500 \mathrm{rpm}$ for $7 \mathrm{~min}$ and transferred to BMMY medium ( $1 \%$ yeast extract, $2 \%$ peptone, $1.34 \% \mathrm{YNB}$ and $4 \times 10^{-4} \%$ biotin) for 2 days with $0.5 \%$ methyl alcohol added every $24 \mathrm{~h}$.

\section{Cloning of genes and sequence analysis of AXE + CBM1 and NPXYN11}

The SV Total RNA Isolation System (Promega, Tokyo, Japan) was used for extracting the total RNA of the strain Talaromyces leycettanus JCM12802 with 3-day-old mycelia in accordance with the specifications. The cDNA fragment of acetyl xylan esterase gene $a x e+c b m 1$ (GenBank accession number MK138893) was used for reverse transcription by the TransScript ${ }^{\circledR}$ One-Step gDNA Removal and cDNA Synthesis SuperMix kit (TransGen, Beijing, China). The peculiar primer sets with restriction sites underlined $(a x e+c b m 1-\mathrm{F} / \mathrm{R})$ were designed according to the presumptive gene sequence and amplified from the cDNA of the axe $+c b m 1$ gene (Table 1). In a similar way, the xylanase npxyn11 gene (GenBank accession number AF123252.1) from Neocallimastix patriciarum was synthesized at Biomed (Beijing, China) by polymerase chain reaction (PCR) with the specific primer npxyn11-F/R (Table 1). The purified PCR product was connected to the pEASY-T3 vector (TransGen) and transformed thermally at $42{ }^{\circ} \mathrm{C}$ for $90 \mathrm{~s}$ into Escherichia coli Fast1-T1 cells.

\section{Construction of mutants}

Sequence and structural analyses (http://www.ncbi.nlm. nih.gov/BLAST/) showed that the acetyl xylan esterase AXE + CBM1 from strain JCM12802 has a specific sequence of the cellulose-binding module CBM1. Four different protein domains are present in this enzyme: a signal peptide (1-19 amino acids), a hydrolase domain (20-309), a S/T-rich linker region (310-342) and a CBM1 domain (343-380). To explore the specific functions of the CBM1 domain, introduced it to the C-terminal of the xylanase NPXYN11. The $c b m 1$ sequence was removed from the acetyl xylan esterase gene $a x e+c b m 1$ and added to the xylanase gene $n p x y n 11$ using peculiar primer sets
Table 1 Primers used in the study

\begin{tabular}{|c|c|}
\hline Prime name & Sequences $\left(5^{\prime} \rightarrow 3^{\prime}\right)$ \\
\hline$a x e+c b m 1-F$ & 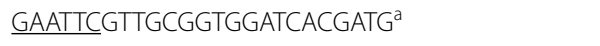 \\
\hline$a x e+c b m 1-R$ & $\underline{\text { GCGGCCGCTCACAGACATTGATAATAGTAATCATTGAC }}$ \\
\hline axe- $\mathrm{F}$ & $\underline{\text { GAATTCGTTGCGGTGGATCACGATGa }}$ \\
\hline axe-R & 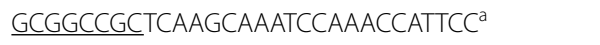 \\
\hline$c b m 1-\mathrm{F}$ & GGTGAGTCTACTGGTGGCGGAA \\
\hline cbm1-R & TCACAGACATTGATAATAGTAATCATT \\
\hline npxyn11-F & $\underline{\text { GAATTCCAAAGTTTCTGTAGTTCAGCTTCT }}{ }^{\mathrm{a}}$ \\
\hline npxyn11-R & 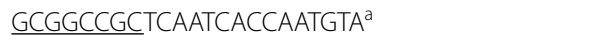 \\
\hline npxyn11gene-F & CAAAGTTTCTGTAGTTCAGCTTCT \\
\hline npxyn11gene-R & ATCACCAATGTAAACCTTTGCGTATG \\
\hline
\end{tabular}

a Nucleotides incorporated for restriction enzyme digestion are underlined. ECoRI: GAATTC; NotI: GCGGCCG

with PCR formed the xylanase gene npxyn11+cbm1 (GenBank accession number MK138894) (Table 1). The annealing temperature is based on primers in the PCR.

\section{Expression and purification of AXE + CBM1, NPXYN11 and mutants}

The recombinant plasmids were linearized by a FastDigest $B g l I I$ restriction enzyme (Thermo Scientific, Waltham, MA, USA), then purified using the Gel Extraction Kit (Omega Bio-Tek, Norcross, GA, USA). The plasmid purifications were performed utilizing the Gene Pulser Xcell electroporation system (Bio-Rad, Hercules, CA, USA), then transformed into P. pastoris GS115 competent cells. Recombinant $P$. pastoris AXEs and NPXYN11 s proteins were obtained by high-speed refrigerated centrifugation (CR21GIII, Hitachi, Japan) in clear liquid at 12,000 rpm for $3 \mathrm{~min}$ at $4{ }^{\circ} \mathrm{C}$, and a $10 \mathrm{kDa}$ molecular weight cut off PES (Sartorius, Germany) was used for ultrafiltration and concentration. Before purifying the crude enzymes, needed to desalinate them using $20 \mathrm{mM}$ citric acid$\mathrm{Na}_{2} \mathrm{HPO}_{4}$ (pH 6.9) for AXE + CBM1 s and $20 \mathrm{mM}$ citric acid- $\mathrm{Na}_{2} \mathrm{HPO}_{4}(\mathrm{pH}$ 7.7) for NPXYN11 s. The desalted enzymes AXE + CBM1 and NPXYN11 were equilibrated with $20 \mathrm{mM}$ citric acid- $\mathrm{Na}_{2} \mathrm{HPO}_{4}(\mathrm{pH}$ 6.9) and citric acid$\mathrm{Na}_{2} \mathrm{HPO}_{4}$ (pH 7.7) and placed into a HiTrap Q Sepharose XL 5-mL fast protein liquid chromatography (FPLC) column (GE Healthcare, Uppsala, Sweden). A flow velocity of $1.5 \mathrm{~mL} \mathrm{~min}{ }^{-1}$ and a linear gradient of $\mathrm{NaCl}$ solution $(0-1.0 \mathrm{M})$ were used to elute enzymes. To respectively use the acetyl xylan esterase enzyme activity and xylanase enzyme activity for measuring their biochemical characterization, sodium dodecyl sulfate-polyacrylamide gel electrophoresis (SDS-PAGE) was employed including a $12 \%$ separation gel and a $5 \%$ stacking gel for observing their protein molecular weight and purity. An Easy Protein Quantitative Kit (TransGen, Beijing, China) was used to detect protein concentration. 


\section{Substrates and enzyme activity assay}

All samples were examined in triplicate. The substrate used for xylanase enzyme activity was beechwood xylan (Sigma, St. Louis, USA), and the standard reaction system included placing $0.1 \mathrm{~mL}$ appropriately diluted enzyme appropriately and $0.9 \mathrm{~mL}$ of $0.5 \%(\mathrm{w} / \mathrm{v})$ beechwood xylan in $0.1 \mathrm{M}$ citric acid- $\mathrm{Na}_{2} \mathrm{HPO}_{4}(\mathrm{pH}$ 6.0) in a $65{ }^{\circ} \mathrm{C}$ thermostatic water bath for $10 \mathrm{~min}$. Afterwards, $1.5 \mathrm{~mL} 3$, 5-dinitrosalicylic acid reagent (DNS) was added and a 5-min immersion in boiling water for the sake of termination reaction. The control samples were added to the enzymes after the addition of DNS, and cooled to room temperature, next all samples were examined using spectrophotometer at $540 \mathrm{~nm}$ absorbance. Under the conditions assayed in this study, the per-minute quantity released by the enzyme of $1 \mu \mathrm{mol}$ reducing sugar was defined as one unit of xylanase enzyme activity.

4-Nitrophenyl acetate ( $p$ NPA, Sigma, St. Louis, USA) was used as the substrate for the acetyl xylan esterase enzyme, and the $p$ NPA solution was prepared from $0.09 \mathrm{~g} p$ NPA dissolved in $5 \mathrm{~mL}$ dimethyl sulfoxide (DMSO, Sigma) in this study. The accurate reaction system contained $0.1 \mathrm{~mL}$ appropriately diluted enzyme, $0.04 \mathrm{~mL} p$ NPA solution and $20 \mathrm{mM}$ citric acid- $\mathrm{Na}_{2} \mathrm{HPO}_{4}$ (pH 6.0) placed at $55^{\circ} \mathrm{C}$ in a thermostatic water bath for $10 \mathrm{~min}$, after which added to $1 \mathrm{~mL}$ absolute ethyl alcohol was added to end the reaction. Under the standard assay conditions, one unit of xylanase enzyme activity was defined as the quantity of $1 \mu \mathrm{mol}$ of $p$-Nitropheno released by the enzyme per minute. The substrate specificities of acetyl xylan esterase enzyme activity were 4-Nitrophenyl acetate (C2), 4-Nitrophenyl butyrate (C4), 4-Nitrophenyl octanoate (C8), 4-Nitrophenyl decanoate (C10) and 4-Nitrophenyl decanoate (C12) from Sigma. 7-Aminocephalosporanic acid (7-ACA) also purchased from Sigma and prepared in a 1\% 7-ACA solution with $0.2 \mathrm{M}$ citric acid- $\mathrm{Na}_{2} \mathrm{HPO}_{4}(\mathrm{pH} 8.0)$.

\section{Biochemical characterization and kinetic parameters assay}

For the xylanase enzyme activity assay, the buffers used are listed as follows: $100 \mathrm{mM}$ glycine- $\mathrm{HCl}(\mathrm{pH} 2.0)$, $100 \mathrm{mM}$ citric acid- $\mathrm{Na}_{2} \mathrm{HPO}_{4}(\mathrm{pH} 3.0-8.0), 100 \mathrm{mM}$ Tris- $\mathrm{HCl}$ (pH 8.0-9.0), and $100 \mathrm{mM}$ glycine- $\mathrm{NaOH}$ (pH 9.0-12.0). The optimum temperature for xylanase enzymes were determined by measurement at the optimal pH from 45 to $75{ }^{\circ} \mathrm{C}$ incremented by $5{ }^{\circ} \mathrm{C}$. By the same token, the optimum $\mathrm{pH}$ was found by measurements in the range of 3.0-8.0 at optimal temperature. The $\mathrm{pH}$ stability of xylanase was examined by placing the enzymes in a water bath at $37{ }^{\circ} \mathrm{C}$ for $1 \mathrm{~h}$ in the abovementioned buffer, then assaying appropriately diluted enzyme at the optimal conditions of $60{ }^{\circ} \mathrm{C}$ and $\mathrm{pH} 5.5$ for $10 \mathrm{~min}$. The controls used uninsulated enzymes. To determine the temperature stability, samples were cultivated at the optimal $\mathrm{pH}$ for $0,5,10,20,30$, and $60 \mathrm{~min}$ at $65{ }^{\circ} \mathrm{C}, 75^{\circ} \mathrm{C}$ and $80{ }^{\circ} \mathrm{C}$, then placed into ice. The control sample was the 0 min cultivation into ice, and residual enzyme activities were calculated at optimal conditions. Through different catalytic concentrations of beechwood xylan at $10 \mathrm{mg} \mathrm{mL}^{-1}, 8 \mathrm{mg} \mathrm{mL}^{-1}, 6 \mathrm{mg} \mathrm{mL}^{-1}, 5 \mathrm{mg} \mathrm{mL}^{-1}$, $4 \mathrm{mg} \mathrm{mL}^{-1}, 2 \mathrm{mg} \mathrm{mL}^{-1}$ and $1 \mathrm{mg} \mathrm{mL}^{-1}$, the LineweaverBurk equation ( $\mathrm{x}$-axis gyroscope as the reciprocal of the substrate concentration, $y$-axis gyroscope as the reciprocal of the enzyme reaction velocity) was used to calculate the Michaelis-Menten constant $\left(K_{\mathrm{m}}\right)$, catalytic rate constant $\left(k_{\text {cat }}\right)$ and maximal velocity $\left(V_{\max }\right)$ under the optimal conditions in triplicate.

To determine the acetyl xylan esterase enzyme activity, buffers were prepared as shown: $20 \mathrm{mM}$ glycine- $\mathrm{HCl}(\mathrm{pH}$ 2.0), $20 \mathrm{mM}$ citric acid- $\mathrm{Na}_{2} \mathrm{HPO}_{4}(\mathrm{pH} 3.0-8.0), 20 \mathrm{mM}$ Tris- $\mathrm{HCl}$ (pH 8.0-9.0), and $20 \mathrm{mM}$ glycine- $\mathrm{NaOH}(\mathrm{pH}$ 9.0-12.0). The optimum temperature for acetyl xylan esterase enzymes was determined by measurements at the optimal pH up $20{ }^{\circ} \mathrm{C}$ to $80{ }^{\circ} \mathrm{C}$ by $10^{\circ} \mathrm{C}$ increments. The optimum $\mathrm{pH}$ was then determined by measurements in the range of 3.0-8.0 at the optimal temperature, but $1 \mathrm{mM} p \mathrm{NPA}$ was used as the substrate for $\mathrm{pH} 7.0-8.0$, and the $p$ NPA concentration was $1 \mathrm{mM}$ for the rest of the conditions. The same procedure was used for the optimum temperature measurements in the range from $20^{\circ} \mathrm{C}$ to $80{ }^{\circ} \mathrm{C}$ per $10{ }^{\circ} \mathrm{C}$ under pH 6.0. For $\mathrm{pH}$ and temperature stability assessments, the same procedure was used as that implemented for the xylanase enzyme activity assay, only different in that the samples were cultivated at the optimal $\mathrm{pH}$ for $0,5,10,20,30$, and $60 \mathrm{~min}$ at $55^{\circ} \mathrm{C}$ and $65^{\circ} \mathrm{C}$. Similarly used $0.5 \mathrm{mM}, 1 \mathrm{mM}, 2 \mathrm{mM}, 3 \mathrm{mM}$, $4 \mathrm{mM}, 6 \mathrm{mM}$ and $8 \mathrm{mM} p \mathrm{NPA}$ were used to measure the $K_{\mathrm{m}}, k_{\mathrm{cat}}$ and $V_{\max }$ values. The calculation of $k_{\text {cat }} / K_{\mathrm{m}}$ for the substrate of 7-ACA was determined by consulting the method of Matsui's research using high performance liquid chromatography (HPLC) (Matsui et al. 1991).

\section{Fabrication of starch-free wheat bran at collaborative experiment}

Approximately $500 \mathrm{~g}$ dry wheat bran was weighed, and washed twice in pure water. Then the cleared wheat bran was placed in $2 \mathrm{~L}$ pure water in a pot and heated until boiling, then let cool slightly before adding $1 \mathrm{~mL}$ thermostable amylase. The above steps were three times. Finally the wheat bran was placed into the stove at $60{ }^{\circ} \mathrm{C}$ overnight. Afterward, the wheat bran was processed with a pulverized and sieved through 50 mesh sieve. Concentration of $2 \%, 5 \%, 10 \%$ starch-free wheat bran were made by weighing $0.4 \mathrm{~g}, 1 \mathrm{~g}$ and $2 \mathrm{~g}$ starch-free wheat bran and dissolving in $20 \mathrm{~mL} 20 \mathrm{mM}$ citric acid- $\mathrm{Na}_{2} \mathrm{HPO}_{4}$ (pH 6.0) in $100 \mathrm{~mL}$ triangular flasks. 
The xylanase solution was calibrated by units of enzyme activity, diluted and put into different test tubes to achieve $25 \mathrm{U}, 50 \mathrm{U}, 100 \mathrm{U}, 200 \mathrm{U}, 400 \mathrm{U}, 800 \mathrm{U}$ and $1600 \mathrm{U}$ solutions. The reaction system included $0.4 \mathrm{~g}$ starch-free wheat bran, $19 \mathrm{~mL}$ pure water and $1 \mathrm{~mL}$ $N P X Y N 11$ at $50{ }^{\circ} \mathrm{C}$ for $1 \mathrm{~h}$ and $100 \mathrm{rpm}$. After the reaction, $1 \mathrm{~mL}$ of the supernatant of the appropriate dilution ratio was collected, and $1.5 \mathrm{~mL}$ DNS was added to detect the reducing sugar content. The addition of xylanase was determined in the early stage by adding different units $(0$ U, $25 \mathrm{U}, 50 \mathrm{U}, 100 \mathrm{U}$ and $200 \mathrm{U}$ ) of acetyl xyaln esterase $\mathrm{AXE}+\mathrm{CBM} 1$, and afterwards, increments of reducing sugar content were used to ensure the addition of acetyl xylan esterase. After determining the amount of xylanase and acetyl xylan esterase, the order of addition and the influence of substrate concentration on the synergistic effect were examined.

The hydrolysis products of starch-free wheat bran were obtained by adding $50 \mathrm{U}$ acetyl xylan esterase AXE or AXE + CBM1 first, then $200 \mathrm{U}$ xylanase NPXYN11 and $N P X Y N 11+C B M 1$, followed by incubation at $50{ }^{\circ} \mathrm{C}$ for $1 \mathrm{~h}$. For detection of the main hydrolysis products, high-performance anion-exchange chromatography (HPAEC) DIONEX ICS-5000 (Thermo Scientific, Sunnyvale, USA) was used with a CarboPac PA200 analysis column $(3 \mathrm{~mm} \times 250 \mathrm{~mm})$ and $1 \mathrm{~mol} \mathrm{~L}^{-1} \mathrm{NaOH}$ eluant. The standard substances for the products were xylose (Sigma), xylobiose, xylotriose, xylotetraose, xylopentaose, and xylohexaose from Megazyme, Ireland.

\section{Result}

Gene cloning and sequence analysis of axe +cbm1, npxyn 11 and their mutants

The full-length cDNA of the acetyl xylan esterase gene $a x e+c b m 1$ was $1083 \mathrm{bp}$ in length according to the display of SnapGene software and was cloned from the cDNA of JCM12802. The CBM1 domain mainly consists of one linker domain and one mature CBM1 domain. In this study, the meaning of the CBM1 domain includes the linker and the mature CBM1. The full-length CBM1 was 213 bp in length. The mature AXE + CBM1 and AXE protein have an isoelectric point of 4.88 , and their molecular were $38.4 \mathrm{kDa}$ and $31.3 \mathrm{kDa}$, respectively, as obtained from the prediction of Vector NTI software. Purified proteins all displayed the same molecular mass on SDS-PAGE (Fig. 1).

\section{Basic properties of $A X E+C B M 1$ and its mutant, $A X E$}

$\mathrm{AXE}+\mathrm{CBM} 1$ and its mutant AXE had the optimal temperature of $55{ }^{\circ} \mathrm{C}$, as well as residual $80 \%$ enzyme activity for AXE + CBM1 and 60\% enzyme activity at the range of 30-60 ${ }^{\circ} \mathrm{C}$ for AXE for the substrate of $p$ NPA (Fig. 2a). If the $p$ NPA concentration is too high, the reaction solution

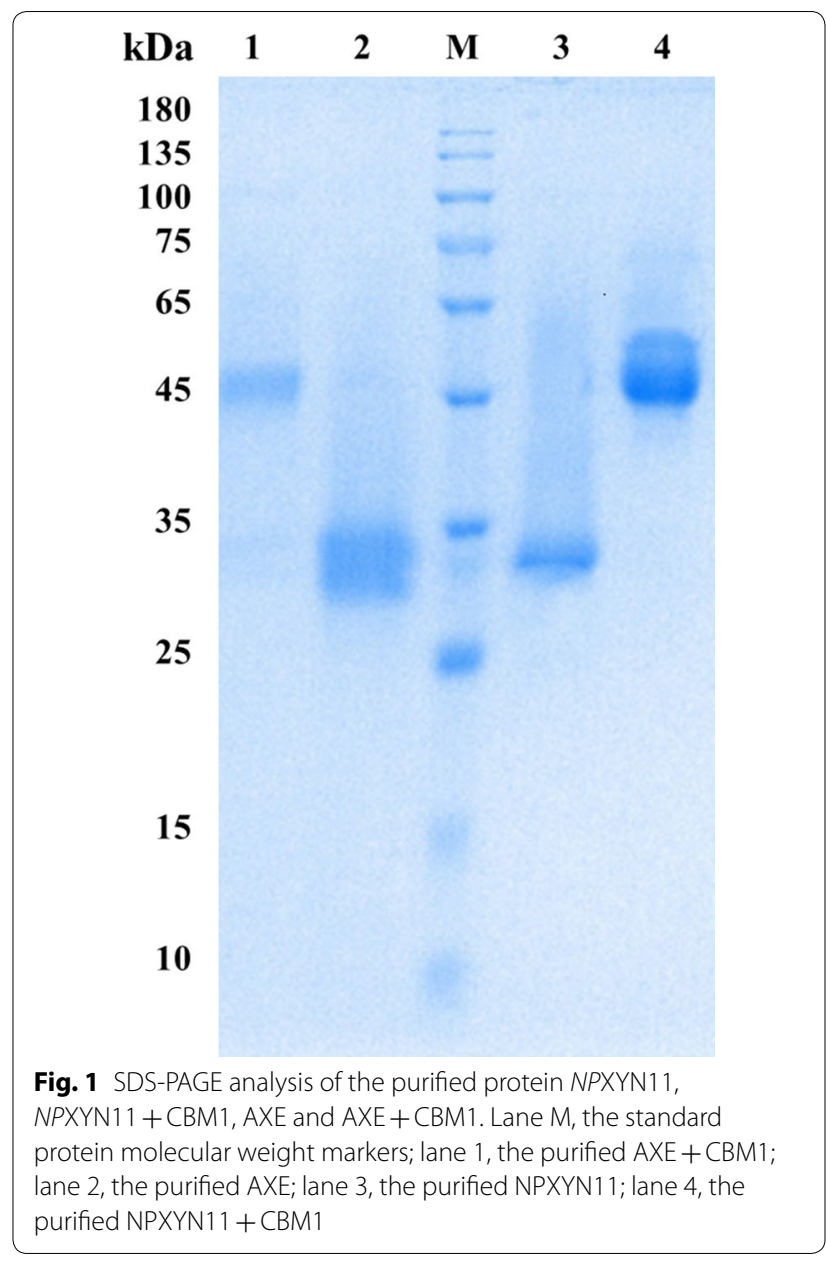

will increasingly grow yellow in portions, which could not be read in the microplate reader at $410 \mathrm{~nm}$, even if the solution was a blank control at alkaline conditions. Hence, the current experiment selected a $4 \mathrm{mmol}$ concentration of $p \mathrm{NPA}$ within $\mathrm{pH} 4.0-6.5$. On account of $\mathrm{pH}$ stability, AXE + CBM1 and AXE exhibited quite broad range of $\mathrm{pH} 3.0-11.0$ and retained more than $60 \%$ of the initial enzyme activity (Fig. 2c). AXE + CBM1 and AXE already showed favorable stability at $55^{\circ} \mathrm{C}$ within $1 \mathrm{~h}$, but at $65{ }^{\circ} \mathrm{C}$ for $1 \mathrm{~h}$, acetyl xylan esterase enzyme activities were lost completely. However, AXE + CBM1 retained $80 \%$ of its enzyme activity and AXE retained $60 \%$ under the condition of $65^{\circ} \mathrm{C}$ for half an hour (Fig. 2d).

When $p$ NPA was used as the substrate, AXE + CBM1 and AXE had light differences in terms of the $K_{\mathrm{m}}, V_{\max }$ and $k_{\text {cat }}$ (Table 1). Though AXE showed lower $k_{\text {cat }} / K_{\mathrm{m}}$ and $K_{\mathrm{m}}$ values than AXE + CBM1, its $V_{\text {max }}$ and $k_{\text {cat }}$ values were higher than did AXE +CBM1 (Table 2). The figures indicate that the CBM1 domain of acetyl xylan esterase was conducive to compatibility between the enzyme and substrate. 

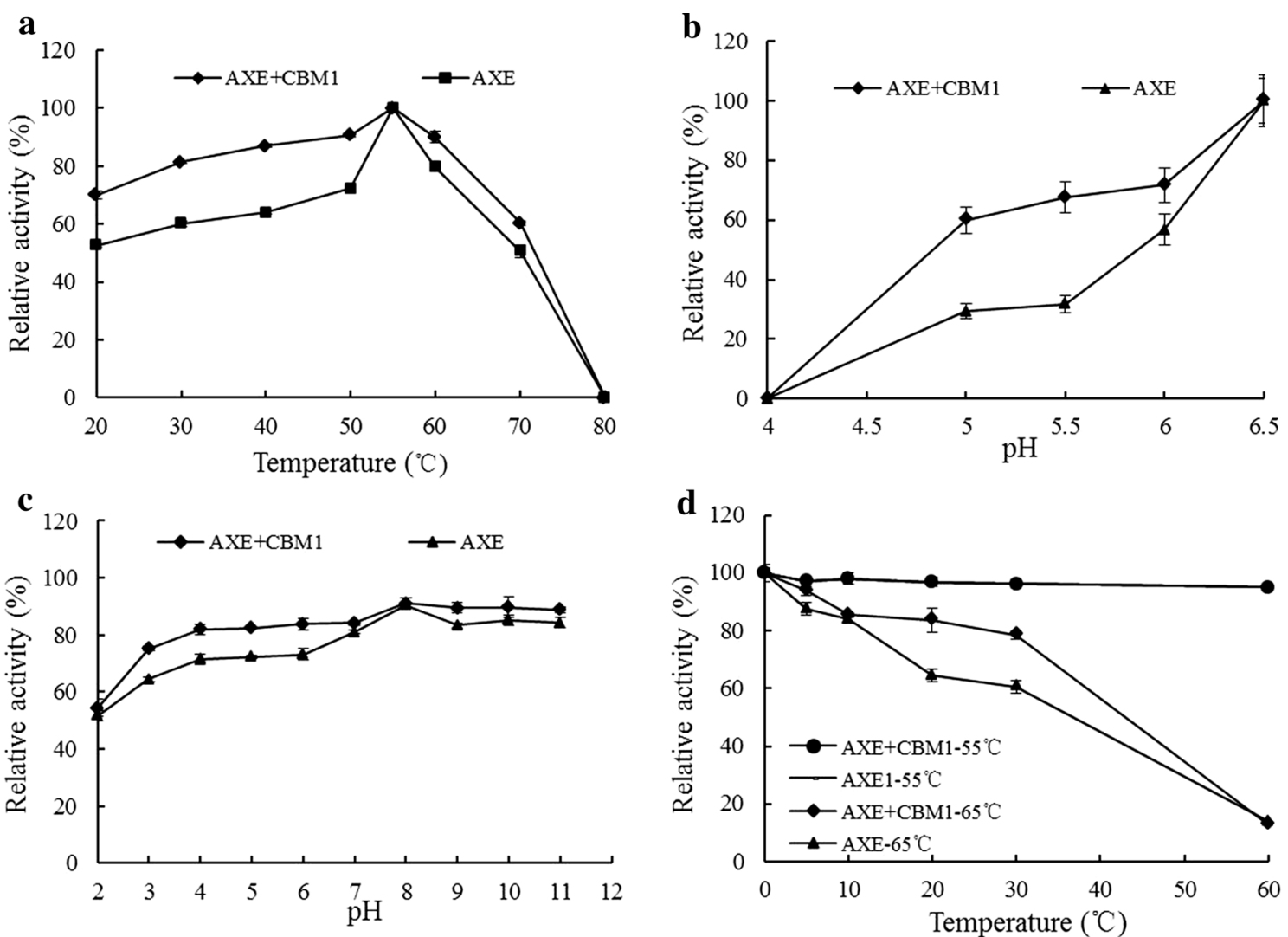

Fig. 2 Characterization of the purified AXE and AXE + CBM1. a Effect of temperature on the AXE and AXE + CBM1 activities. $\mathbf{b}$ Effect of pH on the AXE and AXE + CBM1 activities. $\mathbf{c}$ Stability of $\mathrm{pH}$ on the AXE and AXE + CBM1 activities. $\mathbf{d}$ Thermostability assay on the AXE and AXE + CBM1 activities. Each value in the panel represents the mean $\pm S D(n=3)$

Table 2 Kinetic values of acetyl xylan esterase and xylanase

\begin{tabular}{|c|c|c|c|c|}
\hline Protein & $K_{\mathrm{m}}(\mathrm{mM})$ & $V_{\max }\left(\mu \mathrm{mol} \min ^{-1} \mathrm{mg}^{-1}\right)$ & $k_{\text {cat }}\left(\mathrm{s}^{-1}\right)$ & $k_{\mathrm{cat}} / K_{\mathrm{m}}\left(\mathrm{s}^{-1} \mathrm{mM}^{-1}\right)$ \\
\hline AXE & $0.72 \pm 0.03$ & $625 \pm 21$ & $326 \pm 17$ & $453 \pm 18$ \\
\hline $\mathrm{AXE}+\mathrm{CBM} 1$ & $0.5 \pm 0.02$ & $455 \pm 19$ & $306 \pm 9$ & $612 \pm 12$ \\
\hline Protein & $K_{\mathrm{m}}\left(\mathrm{mg} \mathrm{mL}^{-1}\right)$ & $V_{\max }\left(\mu \mathrm{mol} \min ^{-1} \mathrm{mg}^{-1}\right)$ & $k_{\text {cat }}\left(\mathrm{s}^{-1}\right)$ & $\begin{array}{l}k_{\text {cat }} / K_{m}\left(\mathrm{~mL} \mathrm{~s}^{-1}\right. \\
\left.\mathrm{mg}^{-1}\right)\end{array}$ \\
\hline NPXYN11 & $4.5 \pm 0.6$ & $5128 \pm 166$ & $2085 \pm 26$ & $459 \pm 9$ \\
\hline NPXYN11 + CBM1 & $5.8 \pm 0.7$ & $6536 \pm 191$ & $3437 \pm 19$ & $584 \pm 8$ \\
\hline
\end{tabular}

Compared to experiments using $p \mathrm{NPA}$, AXE + CBM1 and AXE demonstrated extremely low $k_{\text {cat }} / K_{\mathrm{m}}$ values with the substrate 7-ACA. The earlier experiment used $p$ NPA as the substrate to calibrate the enzyme activities of AXE + CBM1 and AXE. Upon on the addition of identical active units of AXE + CBM1 and AXE and reacting with $1 \%$ o 7 -ACA for $1 \mathrm{~h}$, the value of $k_{\text {cat }} / K_{\mathrm{m}}$ of AXE + CBM1 was slightly larger than AXE, with the value of $17.45 \mathrm{mmol}^{-1} \mathrm{~min}^{-1}$ and $15.04 \mathrm{mmol}^{-1} \mathrm{~min}^{-1}$ respectively. This result expressed that the CBM1 domain was related to the catalytic efficiency of AXE + CBM1.

At the optimum conditions of temperature and $\mathrm{pH}$, the efficiency of hydrolysis of acetyl xylan esterase AXE + CBM1 and 4-Nitrophenyl acetate was the highest. In addition, acetyl xylan esterase AXE + CBM1 and 4-Nitrophenyl butyrate (C4) only retained approximately $15 \%$ of the enzyme acyivity compared to the sample with the substrates of 4-Nitrophenyl acetate. Nevertheless 4-Nitrophenyl octanoate (C8), 4-Nitrophenyl decanoate 
(C10), 4-Nitrophenyl decanoate (C12) as the substrate respectively, enzyme activities were not entire detected. In general, acetyl xylan esterase AXE + CBM1 was more in favor of short-chain fatty acids than $p$ NP-ester substrate.

\section{Basic properties of NPXYN11 and its mutant NPXYN11 + CBM1}

The optimal temperatures of NPXYN11 and its mutant NPXYN11+CBM1 were both $65{ }^{\circ} \mathrm{C}$, and NPXYN11 + CBM1 retained $90 \%$ of its enzyme activity or more within the range from 60 to $70{ }^{\circ} \mathrm{C}$ (Fig. 3a). NPXYN11 and NPXYN11 + CBM1 retained more than $70 \%$ enzyme activities at $\mathrm{pH} 4.0-6.0$, and 5.0 was the optimal $\mathrm{pH}$ for both (Fig. 3b). From the diagram results, the thermal stability of NPXYN11 + CBM1 was a little better than NPXYN11. Within the range of pH 4.0-11.0 for $1 \mathrm{~h}, N P X Y N 11$ and NPXYN11+CBM1 retained more than $80 \%$ of their enzyme activities compared with untreated protein. Furthermore they had approximately $100 \%$ enzyme activities at $\mathrm{pH} 5.0-8.0$ for $1 \mathrm{~h}$ (Fig. 3c). After incubation at $65^{\circ} \mathrm{C}$ for $1 \mathrm{~h}, N P X Y N 11$ and $N P X Y N 11+C B M 1$ were stable and retained $95 \%$ enzyme activities. At $75{ }^{\circ} \mathrm{C}$ and $80^{\circ} \mathrm{C}$ for $1 \mathrm{~h}, N P X Y N 11+\mathrm{CBM} 1$ maintained $65 \%$ and $43 \%$ residual enzyme activities respectively, while NPXYN11 had 58\% and 40\% (Fig. 3d).

When beechwood xylan was used as the substrate for NPXYN11 and NPXYN11+CBM1, the values of $V_{\max }$, $k_{\text {cat }}$ and $k_{\text {cat }} / K_{\mathrm{m}}$ all were on the rise (Table 2). From the data in the table, Vmax, $k_{\text {cat }}$ and $k_{\text {cat }} / K_{\mathrm{m}}$ of NPXYN11 were slightly less than those of NPXYN11 + CBM1, indicated that the CBM1 domain was beneficial to the binding of xylanase NPXYN11 and substrate.

\section{The synergistic reaction with xylanase and acetyl xylan esterase}

Xylanase solution was calibrated using units of enzyme activity, diluted and put into different test tubes to achieve different enzymatic units from 25 U-1600 U. Basic of the result in the table below, reducing sugar increment was approximately proportional to the amount of addition at the range of 25-200 U (Fig. 4a). When the additive amount of xylanase was $200 \mathrm{U}$, the yield of reducing sugar was $6 \mu \mathrm{mol} \mathrm{mL} \mathrm{m}^{-1}$ approximately, and when the addition amount of xylanase was increased exponentially, but the amount of reducing sugars was not doubled. This result was the reason why NPXYN11 or
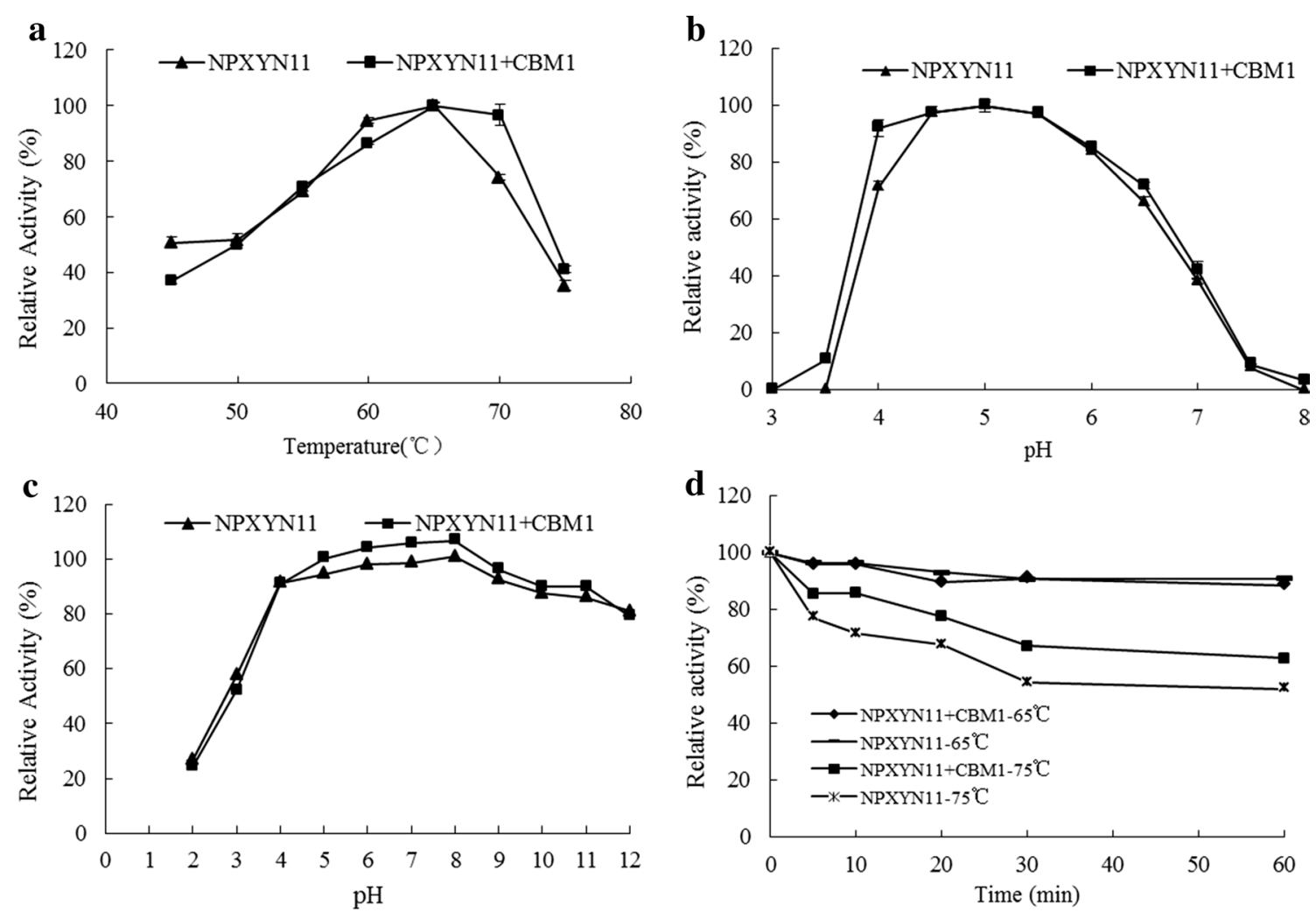

Fig. 3 Characterization of the purified NPXYN11 and NPXYN11 +CBM1. a Effect of temperature on the NPXYN11 and NPXYN11+CBM1 activities. $\mathbf{b}$ Effect of pH on the NPXYN11 and NPXYN11 + CBM1 activities. $\mathbf{c}$ Stability of pH on the NPXYN11 and NPXYN11 + CBM1 activities. d Thermostability assay on the NPXYN11 and NPXYN11 + CBM1 activities. Each value in the panel represents the mean $\pm S D(n=3)$ 

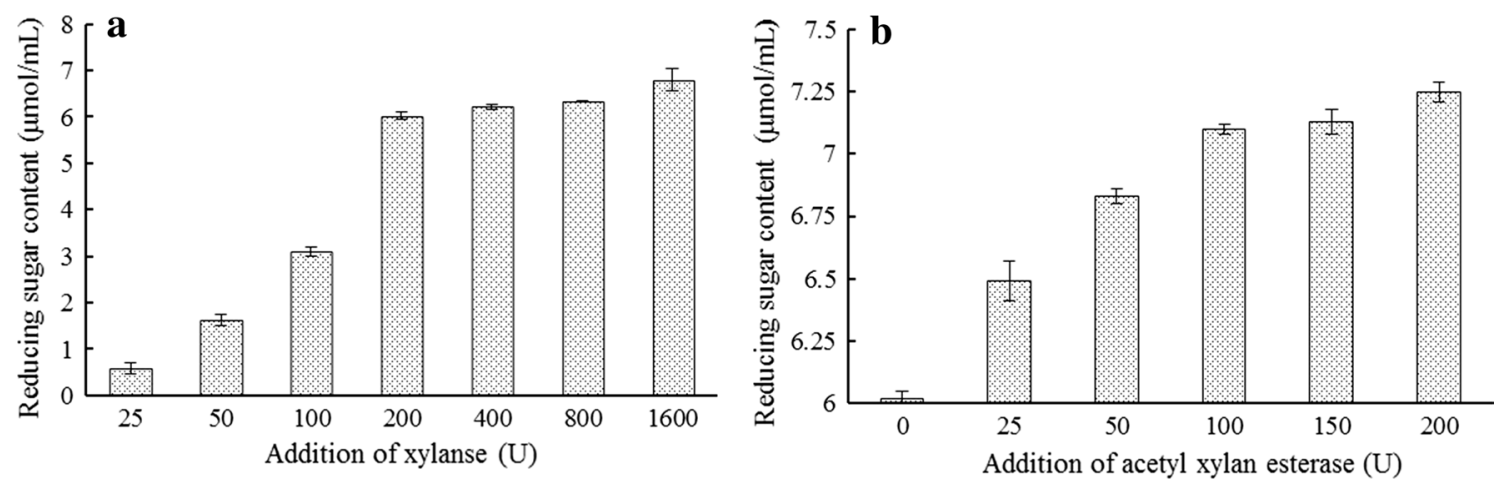

Fig. 4 Determined addition of acetyl xylan esterase and xylanase in starch-free wheat bran experiment as reducing sugar. a The content of reducing sugar produced by xylanase NPXYN11 in different units of activity to the starch-free wheat bran. $\mathbf{b}$ Reducing sugar content on the basic of $200 \mathrm{U}$ xylanase NPXYN11 and different amount acetyl xylan esterase AXE severally

NPXYN11 + CBM1 were added at $200 \mathrm{U}$ in the collaborative experiment below using acetyl xylan esterase and xylanase.

The addition of xylanase was determined in the early stage by adding different units of acetyl xylan esterase $\mathrm{AXE}+\mathrm{CBM} 1$. Afterwards the increment of reducing sugar content was used to ensure the addition of acetyl xylan esterase. According to the following result, the reducing sugar increment was approximately proportional to the amount of addition within the range of 25-50 U (Fig. 4b). When the addition of AXE + CBM1 exceeded $50 \mathrm{U}$, the increment of reducing sugar was less. It was the reason why AXE + CBM1 or AXE was added $50 \mathrm{U}$ in the collaborative experiment of below acetyl xylan esterase and xylanase.

In the early grouping, the addition amounts of acetyl xylan esterase and xylanase were determined and it is found that acetyl xylan esterase was conducive to xylanase activity in the degradation of insoluble substrates. By means of different orders of addition of acetyl xylan esterase and xylanase, single-enzyme and doubleenzyme reactions and the adding order were explored for the collaborative experiment. The experimental results show that the most appropriate solution was the addition of xylanase after acetyl xylan esterase, and the reducing sugar content from this method was the maximum (29\%) under similar conditions (Table 3).

If other conditions were exactly the same, the higher was the substrate concentration or the longer was the reaction time, the more obvious was the promotion of reducing sugar content (Table 4). Compared with xylanase alone, the addition of double-enzymes had a similar effect (Table 5). In terms of the results, the CBM1 domain of acetyl xylan esterase or xylanase was favorable for producing more reducing sugars. Under the comprehensive

Table 3 Order of addition about acetyl xylan esterase and xylanase on starch-free wheat bran

\begin{tabular}{|c|c|c|c|c|}
\hline \multirow[t]{2}{*}{ Order } & \multicolumn{2}{|l|}{ AXE and NPXYN11 } & \multicolumn{2}{|l|}{$\mathrm{AXE}+\mathrm{CBM} 1$ and $N P X Y N 11$} \\
\hline & $\begin{array}{l}\text { Reducing sugar content } \\
\left(\mu \mathrm{mol} \mathrm{mL} L^{-1}\right)\end{array}$ & $\begin{array}{l}\text { Percentage of promotion } \\
\text { with order } 2(\%)\end{array}$ & $\begin{array}{l}\text { Reducing sugar content } \\
\text { ( } \mu \mathrm{mol} / \mathrm{mL})\end{array}$ & $\begin{array}{l}\text { Percentage } \\
\text { of promotion } \\
\text { with order } 2(\%)\end{array}$ \\
\hline $1^{\mathrm{a}}$ & ND & & ND & \\
\hline $2^{\mathrm{b}}$ & $5.97 \pm 0.18$ & & $5.97 \pm 0.18$ & \\
\hline $3^{c}$ & $6.91 \pm 0.11$ & 16 & $7.72 \pm 0.21$ & 29 \\
\hline $4^{d}$ & $6.21 \pm 0.17$ & 4 & $6.33 \pm 0.19$ & 6 \\
\hline $5^{e}$ & $6.51 \pm 0.11$ & 9 & $6.69 \pm 0.02$ & 12 \\
\hline
\end{tabular}

a Only added $50 \mathrm{U}$ acetyl xylan esterase at $50^{\circ} \mathrm{C}$ water bath for $100 \mathrm{rpm}$ at $1 \mathrm{~h}$

b Only added $200 \mathrm{U}$ xylanase at $50^{\circ} \mathrm{C}$ water bath for $100 \mathrm{rpm}$ at $1 \mathrm{~h}$

${ }^{c}$ Added $50 \mathrm{U}$ acetyl xylan esterase first at $50^{\circ} \mathrm{C}$ water bath for $100 \mathrm{rpm}$ at $1 \mathrm{~h}$. Then boiled $5 \mathrm{~min}$ for deactivation and added $200 \mathrm{U}$ xylanase next for reaction at $50{ }^{\circ} \mathrm{C}$ for $100 \mathrm{rpm}$ at $1 \mathrm{~h}$

d Added $200 \mathrm{U}$ xylanase first at $50^{\circ} \mathrm{C}$ water bath for $100 \mathrm{rpm}$ at $1 \mathrm{~h}$. Then boiled $5 \mathrm{~min}$ for deactivation and added $50 \mathrm{U}$ acetyl xylan esterase next for reaction at $50{ }^{\circ} \mathrm{C}$ for $100 \mathrm{rpm}$ at $1 \mathrm{~h}$

e Simultaneously added $50 \mathrm{U}$ acetyl xylan esterase and $200 \mathrm{U}$ xylanase for reaction at $50^{\circ} \mathrm{C}$ water bath at $1 \mathrm{~h}$ for $100 \mathrm{rpm}$ 
Table 4 The impact of starch-free wheat bran concentration about acetyl xylan esterase and xylanase

\begin{tabular}{lccc}
\hline Protein & $\begin{array}{l}\text { Starch-free wheat bran concentration } \\
(\%)\end{array}$ & $\begin{array}{l}\text { Reducing sugar content at 60 min } \\
\left(\mu \mathbf{m o l ~ m L}^{-1}\right)\end{array}$ & $\begin{array}{l}\text { Percentage } \\
\text { of promotion } \\
(\%)\end{array}$ \\
\hline NPXYN11 & 2 & $5.56 \pm 0.03$ \\
NPXYN11 & 5 & $8.92 \pm 0.11$ \\
NPXYN11 & 10 & $15.71 \pm 0.16$ & 8 \\
NPXYN11+CBM1 & 2 & $6.03 \pm 0.04$ & 14 \\
NPXYN11+CBM1 & 5 & $10.19 \pm 0.12$ & 21 \\
NPXYN11+CBM1 & 10 & $19.01 \pm 0.21$ & \\
\hline
\end{tabular}

Table 5 The influence of the CBM1 domain with/without acetyl xylan esterase and/or xylanase on starch-free wheat bran

\begin{tabular}{|c|c|c|c|}
\hline Protein & $\begin{array}{l}\text { Starch-free wheat bran } \\
\text { concentration (\%) }\end{array}$ & $\begin{array}{l}\text { Reducing sugar content } \\
\left(\mu \mathrm{mol} \mathrm{mL} L^{-1}\right)\end{array}$ & $\begin{array}{l}\text { Percentage } \\
\text { of promotion } \\
\text { (\%) }\end{array}$ \\
\hline AXE and NPXYN11 & 2 & $6.94 \pm 0.03$ & \\
\hline AXE and NPXYN11 & 5 & $10.28 \pm 0.09$ & \\
\hline AXE and NPXYN11 & 10 & $17.40 \pm 0.04$ & \\
\hline $\mathrm{AXE}+\mathrm{CBM} 1$ and $\mathrm{NPXYN} 11+\mathrm{CBM} 1$ & 2 & $7.66 \pm 0.1$ & 10 \\
\hline $\mathrm{AXE}+\mathrm{CBM} 1$ and $\mathrm{NPXYN} 11+\mathrm{CBM} 1$ & 5 & $12.27 \pm 0.07$ & 19 \\
\hline $\mathrm{AXE}+\mathrm{CBM} 1$ and $N P X Y N 11+\mathrm{CBM} 1$ & 10 & $23.18 \pm 0.08$ & 34 \\
\hline
\end{tabular}

consideration, the cooperative experiment used the combination NPXYN11+CBM1 and AXE+CBM1 with combination NPXYN11 and AXE to degrade 10\% starch-free wheat bran at $50{ }^{\circ} \mathrm{C}$ and $100 \mathrm{rpm}$ for $1 \mathrm{~h}$. The result showed that reducing sugar content was ultimately increased $34 \%$ when then reaction was performed with the addition of NPXYN11 + CBM1 and AXE + CBM1.

\section{Discussion}

Xylooligosaccharides are functional oligosaccharides with unique physiological activities, linked with multiple xylose molecules via $\beta-1,4$-glycosidic bonds. Due to their remarkable functional benefits in feed production, xylooligosaccharides have been extensively studied by increasing numbers of scholars. A study showed that day-old, healthy Arbor Acres broilers that were fed a basal diet (maize-soybean meal) containing $10 \mathrm{~g} \mathrm{~kg}^{-1}$ of xylooligosaccharides were observed to gain $9.44 \%$ more weight on the 59th day when compared to the control group that did not have xylooligosaccharides in their diet (Sun et al. 2013). Moreover, the avian influenza H5N1 virus incidence was significantly higher (by $33.78 \%$ ) than in the control group by $33.78 \%$ for when compared to the treatment group with that had the same amount of xylooligosaccharides added to their feed. The solubility of the bone mineral bioapatite was also found to be lower and the crystallinity was found to be higher (leading to improved bone mineralization) than in the experimental group after adding $0.1-0.5 \mathrm{~g} \mathrm{~kg}^{-1}$ of xylooligosaccharides during the growing and fattening stage in pigs when compared to that of the control group (Wang et al. 2017). In mice with adenine-induced chronic kidney disease, xylooligosaccharides interfered with the reduction process of six out of nine bacterial genera in chronic kidney diseases (Yang et al. 2018). Xylooligosaccharides also have important roles in increasing intestinal probiotics and improving the intestinal microecological environment (Ho et al. 2014). A study in male Sprague-Dawley rats showed that the serum triglyceride concentrations were reduced by $34 \%$ when mice were supplemented with $60 \mathrm{~g} \mathrm{~kg}^{-1}$ xylooligosaccharides in their feed after 35 days, and that Bifidobacterium levels increased and Escherichia coli levels decreased in cecal microbiota (Hsu et al. 2004). Adding xylooligosaccharides to the feed effectively reduce its feed production coefficient, improved the growth performance of poultry, and improve animal immunity and metabolic functions.

Preparation methods using corncobs, the main raw material for xylooligosaccharide production, mainly include acid-base extraction (Quinones et al. 2015), hot water hydrolysis (Vazquez et al. 2000), steam explosion (Shimizu et al. 1998) and enzymatic hydrolysis (Strelova and Chuvina 2008). However, the high costs involved in alkali extraction (Qi et al. 2009) and the need for a series of complex processes, such as ethanol dissolution, precipitation, desalination and 
decolorization limit its efficient utilization. For example, xylanase is used to decompose the xylan backbone, and coenzymes such as acetyl xylan esterase and $\alpha-\mathrm{L}-$ arabinofuranosidase are used to degrade side chains in the enzymatic degradation of xylan from corn cobs. However, the enzymatic hydrolysis of corn husks and corn cobs is extremely inefficient. Surprisingly, direct hydrolysis of wheat bran and corn husks by xylanase resulted in 7-8 times (data not shown) more product from the wheat bran reducing sugar content when compared to the same in the corn husk. Therefore, one-step enzymatic hydrolysis provides a possibility for producing xylooligosaccharides. Although it is inefficient, onestep enzymatic hydrolysis is environmental-friendly. Thus, it is a good strategy to research the synergistic effects of enzymes and to improve the binding ability of enzymes for insoluble substrates.

Carbohydrate-binding modules (CBMs) exist in many glycoside hydrolases including xylanases, and are independent and non-catalytic areas of the structure (Antoine et al. 2004; Rodriguez-Sanoja et al. 2009). Because of its significant role in improving the catalytic efficiency of enzymes, many researchers have studied and reported on this module. While comparing the kinetic constants of CBM1, CBM2, CBM3, CBM4, CBM10, CBM72 in cellulase Umcel9A and CBM-chimeric Umcel9A, the $k_{\text {cat }} / K_{\mathrm{m}}$ values of the chimeric enzymes were 1.09-4.44 times more than those of the wild-type (Duan et al. 2017). Furthermore, the catalytic efficiency of acetyl xylan esterase AnAXE-CtCBM3 was approximately $5 \%$ more than that of wild-type AnAXE towards $p$ NPA (Mai-Gisondi et al. 2015). While comparing of the acetyl xylan esterase properties of AXE + CBM1 and AXE from Talaromyces leycettanus JCM12802, the optimum conditions were found to be uniform and the $\mathrm{pH}$ stability was equally broad as well. This result indicated that the elimination of the CBM1 structural domain had no effect on the basic enzymatic properties of AXE. To study xylanase, NPXYN11 (GenBank: AF123252.1) from Neocallimastix patriciarum and belonging to the GH11 family was used. Because of its excellent thermal stability and high specific activity, many scholars, such as Bu et al. (2018), Chen et al. (2001), Malunga and Beta (2015), and Krause et al. (2001), have conducted detailed studies with respect to this xylanase in recent years. Although it has satisfactory industrial application prospects, NPXYN11 has not a CBM domain and therefore, the CBM1 domain was introduced at the $\mathrm{C}$-terminal of the protein. Upon comparing the basic nature of NPXYN11 and NPXYN11 + CBM1, their temperature and $\mathrm{pH}$ of optimum and stability were found to basically be the same. This means that the addition of an exogenous CBM1 domain did not affect the basic properties of NPXYN11. However, the deletion and addition of the CBM1 domain was found to influence kinetic parameters (Table 2). When the $k_{\text {cat }} / K_{\mathrm{m}}$ values for AXE + CBM1 and NPXYN11+CBM1 were compared with those of AXE and NPXYN11 respectively, a rising trend of approximately $25 \%-35 \%$ was observed.

Furthermore, acetylation was shown to limit the degradation of acylated xylanase (Selig et al. 2009); however, the addition of acetyl xylan esterase solved this problem. The synergistic reaction was reflected as follows: acetyl xylan esterase helped xylanase to degrade xylan in order to produce more reducing sugars, and xylanase assisted acetyl xylan esterase in removing acetylates in order to generate acetic acid. The $\alpha$-L-arabinofuranosidase is an assistant enzyme responsible for xylan depolymerization, and is widely studied because it can assist xylanase during reactions (Goncalves et al. 2012). The amounts of reducing sugars produced by $\alpha-\mathrm{L}$-arabinofuranosidase and xylanase from oat-spelt xylan were confirmed to be greater by about approximately 30\% when compared with the amount from single xylanase (Huang et al. 2017). The outstanding synergistic effects of $\alpha-L-$ arabinofuranosidase Ac-Abf51A and xylanase XynBE18 was observed to increase by 2.92 folds during water-soluble wheat arabinoxylan degradation (Yang et al. 2015a). However, only a few studies exist on the synergistic effects of acetyl xylan esterase and xylanase, especially with respect to wheat bran as a natural substrate. After previous exploration, $200 \mathrm{U}$ of xylanase $50 \mathrm{U}$ of acetyl xylan esterase were found to exert the maximum effect (Fig. 4). Moreover, the addition of acetyl xylan esterase and xylanase, in that order, produced the largest amount of reducing sugars (Table 3). The synergistic effect was also observed to be the best when the auxiliary enzyme first reacted with the substrate and then added to the main chain enzyme. This was consistent with the 1.2-fold increase found in the study showed the synergistic effect of xylanase and $\alpha$-L-arabinofuranosidase on birchwood xylan (Yang et al. 2015b). When AXE + CBM1 or AXE was added first, the respective reducing sugar content were $29 \%$ or $16 \%$ higher than that produced when only xylanase was reacted. Since side chain groups are sterically hindered by the degradation of main chain enzymes, acetyl groups may affect the degradation of xylan structures via xylanase. Therefore, the removal of side chain substituent via side chain enzyme is more conducive to the degradation activity of the main chain enzyme. It was speculated that acetyl xylan esterase excised the acetyl group on the side chain of xylanase, which allowed xylanase to move closer to the main chain of xylan. Notably, the effect of xylanase with the CBM1 domain was more obvious at higher substrate concentrations. The amount of reducing sugars were also observed to be slightly higher when AXE or AXE + CBM1 were added 
later when compared to xylanase, the content of reducing sugar contents were $4 \%$ or $6 \%$ higher than that produced when only xylanase was added. The reason for this phenomenon may be because the main chain degradation of xylan by xylanase generates different sizes of fragments, then acetyl xylan esterase effects on these fragments, resulting in a small amount of reduction and thus, so a small increase reducing sugars increased less (Zhu et al. 2016). When all conditions were optimal, NPXYN11+CBM1 and AXE + CBM1 produced $34 \%$ more reducing sugars than NPXYN11 and AXE independently.

Both xylobiose and xylotriose are basic components of xylooligosaccharides. Interestingly higher are the activity and purity of xylooligosaccharide products are correlated with higher xylobiose and xylotriose contents (Antoine et al. 2004). In addition, xylobiose is an alternative healthy sweetener that helps avoid obesity. A study by Soo-min Lim showed that adding $10 \%$ of xylobiose to mouse diets effectively suppressed fat accumulation in the mesenteric (29\%), subcutaneous (22\%), and perirenal (16\%) deposits (Lim et al. 2018). Furthermore, the expressed recombinant xylanase Xyn2 in P. pastoris and its products from hydrolyzed oat-spelt xylan were mostly xylotriose, and supplementation with $500 \mathrm{U} \mathrm{kg}^{-1}$ of Xyn2 on average produced a daily body-weight gain of $16.9 \%$ in weaned pigs (He et al. 2009). In this study, the results showed that when wheat bran was used as a substrate, not only did acetyl xylan esterase and xylanase together with the CBM1 domain produce nearly $35 \%$ more reducing sugars than enzyme reactions without the CBM1 domain, but the introduction of xylanase into the CBM1 domain also did not change the composition of xylose, the highest proportion of which was $86 \%$, that consisted of $49 \%$ xylobiose and $37 \%$ xylotriose.

\section{Abbreviations \\ CBM: carbohydrate-binding module; GH: glycoside hydrolase; AXE + CBM1: a full-length acetyl xylan esterase from Talaromyces leycettanus JCM12802; AXE: the CBM1 and Linker domain removed AXE + CBM1; NPXYN11: a GH11 family xylanase from Neocallimastix patriciarum; NPXYN11 + CBM1: the CBM1 and Linker domain added NPXYN11.}

\section{Authors' contributions}

$Y Z$ and $B G$ designed the experiment, analyzed the results. $Y Z$ wrote the manuscript and performed most lab work. HY, XY, HK, JC had contribution in conducting few experiments. All authors read and approved the final manuscript.

\section{Acknowledgements}

Not applicable.

\section{Competing interests}

The authors declare that they have no competing interests.

\section{Availability of data and materials}

The dataset supporting the conclusions of this articled within the article and its additional files.
Consent for publication

Not applicable.

Ethics approval and consent to participate

Not applicable.

\section{Funding}

This study was supported by grants from the National Key R\&D Program of China (2016YFD0501409-02), the Chinese Academy of Agricultural Science and Technology Innovation Project (CAAS-XTCX2016011-01) and the National Chicken Industry Technology System of China (CARS-41).

\section{Publisher's Note}

Springer Nature remains neutral with regard to jurisdictional claims in published maps and institutional affiliations.

Received: 25 October 2018 Accepted: 23 January 2019

Published online: 29 January 2019

\section{References}

Antoine C, Peyron S, Lullien-Pellerin V, Abecassis J, Rouau X (2004) Wheat bran tissue fractionation using biochemical markers. J Cereal Sci 39(3):387-393

Bastawde KB (1992) Xylan structure, microbial xylanases, and their mode of action. World J Microbiol Biotechnol 8(4):353-368

Biely P, Mislovicova D, Toman R (1985) Soluble chromogenic substrates for the assay of endo-1,4-beta-xylanases and endo-1,4-beta-glucanases. Anal Biochem 144(1):142-146

Biely P, Vrsanska M, Tenkanen M, Kluepfel D (1997) Endo-beta-1,4-xylanase families: differences in catalytic properties. J Biotechnol 57(1-3):151-166

Bu Y, Cui Y, Peng Y, Hu M, Tian Y, Tao Y, Wu B (2018) Engineering improved thermostability of the GH11 xylanase from Neocallimastix patriciarum via computational library design. Appl Microbiol Biotechnol 102(8):3675-3685

Chakdar H, Kumar M, Pandiyan K, Singh A, Nanjappan K, Kashyap PL, Srivastava AK (2016) Bacterial xylanases: biology to biotechnology. 3 Biotech 6(2):150

Chen YL, Tang TY, Cheng KJ (2001) Directed evolution to produce an alkalophilic variant from a Neocallimastix patriciarum xylanase. Can J Microbiol 47(12):1088-1094

Chen LL, Zhang M, Zhang DH, Chen XL, Sun CY, Zhou BC, Zhang YZ (2009) Purification and enzymatic characterization of two beta-endoxylanases from Trichoderma sp. K9301 and their actions in xylooligosaccharide production. Bioresour Technol. 100(21):5230-5236

Collins T, Gerday C, Feller G (2005) Xylanases, xylanase families and extremophilic xylanases. FEMS Microbiol Rev 29(1):3-23

Cybinski DH, Layton I, Lowry JB, Dalrymple BP (1999) An acetylxylan esterase and a xylanase expressed from genes cloned from the ruminal fungus Neocallimastix patriciarum act synergistically to degrade acetylated xylans. Appl Microbiol Biotechnol 52(2):221-225

Duan CJ, Huang MY, Pang H, Zhao J, Wu CX, Feng JX (2017) Characterization of a novel theme $\mathrm{C}$ glycoside hydrolase family 9 cellulase and its CBMchimeric enzymes. Appl Microbiol Biotechnol 101(14):5723-5737

Goncalves TA, Damasio AR, Segato F, Alvarez TM, Bragatto J, Brenelli LB, Citadini AP, Murakami MT, Ruller R, Paes Leme AF, Prade RA, Squina FM (2012) Functional characterization and synergic action of fungal xylanase and arabinofuranosidase for production of xylooligosaccharides. Bioresour Technol 119(5):293-299

He J, Yu B, Zhang KY, Chen DW (2009) Functional characterization of a recombinant thermostable xylanase from Pichia pastoris: a hybrid enzyme being suitable for xylooligosaccharides production. Biochem Eng J 48(1):87-92

Ho AL, Carvalheiro F, Duarte LC, Roseiro LB, Charalampopoulos D, Rastali RA (2014) Production and purification of xylooligosaccharides from oil palm empty fruit bunch fibre by a non-isothermal process. Bioresour Technol 152(1):526-529

Hsu CK, Liao JW, Chung YC, Hsieh CP, Chan YC (2004) Xylooligosaccharides and fructooligosaccharides affect the intestinal microbiota and precancerous colonic lesion development in rats. J Nutr 134(6):1523-1528 
Huang D, Liu J, Qi YF, Yang KX, Xu YY, Feng L (2017) Synergistic hydrolysis of xylan using novel xylanases, beta-xylosidases, and an alpha-L-arabinofuranosidase from Geobacillus thermodenitrificans NG80-2. Appl Microbiol Biotechnol 101(15):6023-6037

Krause DO, Bunch RJ, Dalrymple BD, Gobius KS, Smith WJ, Xue GP, McSweeney CS (2001) Expression of a modified Neocallimastix patriciarum xylanase in Butyrivibrio fibrisolvens digests more fibre but cannot effectively compete with highly fibrolytic bacteria in the rumen. J Appl Microbiol 90(3):388-396

Lim SM, Kim E, Shin JH, Seok PR, Jung S, Yoo SH, Kim Y (2018) Xylobiose prevents high-fat diet induced mice obesity by suppressing mesenteric fat deposition and metabolic dysregulation. Molecules 23(3):705-721

Maes C, Delcour JA (2002) Structural characterisation of water-extractable and water-unextractable arabinoxylans in wheat bran. J Cereal Sci 35(3):315-326

Mahadevan SA, Wi SG, Kim YO, Lee KH, Bae HJ (2011) In planta differential targeting analysis of Thermotoga maritima Cel5A and CBM6-engineered Cel5A for autohydrolysis. Transgenic Res 20(4):877-886

Mai-Gisondi G, Turunen O, Pastinen O, Pahimanolis N, Master ER (2015) Enhancement of acetyl xylan esterase activity on cellulose acetate through fusion to a family 3 cellulose binding module. Enzyme Microb Technol 79-80:27-33

Malunga LN, Beta T (2015) Antioxidant capacity of arabinoxylan oligosaccharide fractions prepared from wheat aleurone using Trichoderma viride or Neocallimastix patriciarum xylanase. Food Chem 167:311-319

Matsui I, Ishikawa K, Matsui E, Miyairi S, Fukui S, Honda K (1991) Subsite structure of Saccharomycopsis alpha-amylase secreted from Saccharomyces cerevisiae. J Biochem 109(4):566-569

Mcdermid KP, Forsberg CW, MacKenzie CR (1990) Purification and properties of an acetyl xylan esterase from Fibrobacter succinogenes S85. Appl Environ Microbiol 56(12):3805-3810

Miao Y, Li P, Li G, Liu D, Druzhinina IS, Kubicek CP, Shen Q, Zhang R (2017) Two degradation strategies for overcoming the recalcitrance of natural lignocellulosic xylan by polysaccharides-binding GH10 and $\mathrm{GH} 11$ xylanases of filamentous fungi. Environ Microbiol 19(3):1054-1064

Peralta AG, Venkatachalam S, Stone SC, Pattathil S (2017) Xylan epitope profiling: an enhanced approach to study organ development-dependent changes in xylan structure, biosynthesis, and deposition in plant cell walls. Biotechnol Biofuels 10(1):245-258

Puls J, Tenkanen M, Korte HE, Poutanen K (1991) Products of hydrolysis of beechwood acetyl-4-O-methylglucuronoxylan by a xylanase and an acetyl xylan esterase. Enzyme Microb Technol 13(6):483-486

Qi BK, Chen XR, Shen F, Su Y, Wan YH (2009) Optimization of enzymatic hydrolysis of wheat straw pretreated by alkaline peroxide using response surface methodology. Ind Eng Chem Res 48(15):7346-7353
Quinones TS, Retter A, Hobbs PJ, Budde J, Heiermann M, Plochl M, Ravella SR (2015) Production of xylooligosaccharides from renewable agricultural lignocellulose biomass. Biofuels 6(3-4):147-155

Rastall RA (2010) Functional oligosaccharides: application and manufacture. Annu Rev Food Sci Technol 1:305-339

Reddy SS, Krishnan C (2016) Production of high-pure xylooligosaccharides from sugarcane bagasse using crude beta-xylosidase-free xylanase of Bacillus subtilis KCX006 and their bifidogenic function. Lwt Food Sci Technol 65:237-245

Rodriguez-Sanoja R, Oviedo N, Escalante L, Ruiz B, Sanchez S (2009) A single residue mutation abolishes attachment of the CBM26 starch-binding domain from Lactobacillus amylovorus alpha-amylase. J Ind Microbiol Biotechnol 36(3):341-346

Selig MJ, Adney WS, Himmel ME, Decker SR (2009) The impact of cell wall acetylation on corn stover hydrolysis by cellulolytic and xylanolytic enzymes. Cellulose 16(4):711-722

Shimizu K, Sudo K, Ono H, Ishihara M, Fujii T, Hishiyama S (1998) Integrated process for total utilization of wood components by steam-explosion pretreatment. Biomass Bioenergy 14(3):195-203

Strelova O, Chuvina NA (2008) Isolation of blood caffeine as a model substance by enzymatic hydrolysis. Sud Med Ekspert 51(4):28-31

Sun Z, Lv W, Yu R, Yu J, Liu H, Sun W, Wang Z, Li J, Shan Z, Qin Y (2013) Effect of a straw-derived xylooligosaccharide on broiler growth performance, endocrine metabolism, and immune response. Can J Vet Res 77(2):105-109

Vazquez MJ, Alonso JL, Dominguez H, Parajo JC (2000) Xylooligosaccharides: manufacture and applications. Trends Food Sci Technol 11(11):387-393

Wang S, Zhang P, Kong X, Xie S, Li Q, Li Z, Zhou Z (2017) Delicate changes of bioapatite mineral in pig femur with addition of dietary xylooligosaccharide: evidences from raman spectroscopy and ICP. Animal Sci J 88(11):1820-1826

Yang W, Bai Y, Yang P, Luo H, Huang H, Meng K, Shi P, Wang Y, Yao B (2015a) A novel bifunctional GH51 exo-alpha-L-arabinofuranosidase/endo-xylanase from Alicyclobacillus sp. A4 with significant biomass-degrading capacity. Biotechnol Biofuels 8(1):197-208

Yang X, Shi P, Ma R, Luo H, Huang H, Yang P, Yao B (2015b) A new GH43 alphaarabinofuranosidase from Humicola insolens $Y 1$ : biochemical characterization and synergistic action with a xylanase on xylan degradation. Appl Biochem Biotechnol 175(4):1960-1970

Yang J, Li Q, Henning SM, Zhong J, Hsu M, Lee R, Long J, Chan B, Nagami GT, Heber D, Li Z (2018) Effects of prebiotic fber xylooligosaccharide in adenine-induced nephropathy in mice. Mol Nutr Food Res 62(15):14-27

Zhu T, Yao HE, Yang B, Liu J, Minchen W (2016) Combinative degradation of xylan with acetyl xylan esterase and xylanase. J Food Sci Biotechnol 35(4):375-380

\section{Submit your manuscript to a SpringerOpen ${ }^{\circ}$ journal and benefit from:}

- Convenient online submission

- Rigorous peer review

- Open access: articles freely available online

- High visibility within the field

- Retaining the copyright to your article

Submit your next manuscript at springeropen.com 